Check for updates

Cite this: RSC Adv., 2018, 8, 6192

\title{
Separation of bovine hemoglobin using novel magnetic molecular imprinted nanoparticles
}

\author{
Yujie Su, ${ }^{\text {ab }}$ Bixia Qiu, (D) ${ }^{\text {ab }}$ Cuihua Chang, ${ }^{\text {ab }}$ Xin Li, ${ }^{\text {ab }}$ Mengqi Zhang, ${ }^{\text {ab }}$ Bei Zhou ${ }^{c}$ \\ and Yanjun Yang *ab
}

Magnetic molecular imprinted nanoparticles (MMIPs), combining the progressiveness of magnetic nanoparticles and surface molecular imprinting technology, have attracted increasing attention because of the high efficiency and specificity in isolation and enrichment of the target protein. This study focused on the preparation of bovine hemoglobin MMIPs with bovine hemoglobin $(\mathrm{BHb})$ as the template protein and the molecular imprinted polymer covering the functional magnetic nanoparticles modified with silane and acrylic groups. The physicochemical characteristics as well as the dynamics and isothermal adsorption properties of the generated nanoparticles were investigated to determine their efficiency and specificity in the adsorption of target protein. The maximum adsorption of the target protein was $169.29 \mathrm{mg} \mathrm{g}^{-1}$ at a specific $\mathrm{pH}$, which was much larger than those obtained in some other research reports. MMIPs showed favorable selectivity towards $\mathrm{BHb}$ in a mixture of three different proteins. The results indicated the significant effects and broad prospects of MMIPs in the isolation and enrichment of specific proteins in the field of food, medicine and biological research.

Received 15th November 2017 Accepted 23rd December 2017

DOI: $10.1039 / \mathrm{c} 7 \mathrm{ra12457k}$

rsc.li/rsc-advances polymerization, ${ }^{\mathbf{1 4}}$ surface-initiated atom and transfer radical polymerization, ${ }^{15}$ has attracted increasing attention due to its small mass transfer resistance, high imprinting efficiency and fast adsorption rate. The surface molecular imprinting technique refers to molecule imprinting polymerization on the surface of solid supporters, which includes two basic types. One is on the surface of pores inside the supporters, such as mesoporous materials; the other is on the surface of microspheres, such as silica particles, graphene particles, $\mathrm{Fe}_{3} \mathrm{O}_{4}$ magnetic nanoparticles and nanotubes. ${ }^{16}$ Although these surface imprinted materials display the characteristics of high imprinting efficiency, most of them are difficult to separate because of the hydrophilic groups and complicated precipitation process. Magnetic molecular imprinted nanoparticles (MMIPs) combining magnetic susceptibility with a surface molecular imprinted polymer not only achieve high selectivity and adsorption, but also promote the effective separation of the matrix from the solution, thus facilitating the capture of the target molecules.

It is well known that proteins showing impeded diffusion in traditional monolithic imprints, insolubility in common imprinting solvents, general flexibility and instability have restricted the application of the protein molecular imprinting technique. ${ }^{17}$ However, the recognition, adsorption, separation and enrichment of proteins by MMIPs have recently gained plenty of attention. ${ }^{\mathbf{1 8}}$ Jing et al. have prepared multifunctional lysozyme-imprinted nanoparticles for lysozyme recognition and adsorption. ${ }^{19}$ Li et al. have successfully synthesized bovine hemoglobin surface-imprinted polystyrene (PS) nanoparticles
${ }^{a}$ State Key Laboratory of Food Science and Technology, Jiangnan University, Wuxi 214122, PR China

${ }^{b}$ School of Food Science and Technology, Jiangnan University, Lihu Avenue 1800, Wuxi, 214122, PR China. E-mail: yangyj@jiangnan.edu.cn; Fax: +86-510-85329080; Tel: +86-510-85329080

'Jiangsu Kang De Egg Industry Co., Ltd., Nantong 226600, PR China 
with magnetic susceptibility ${ }^{\mathbf{2 0}}$ and poly(3-amino-phenylboronic acid)-coated MMIPs ${ }^{21}$ with high adsorption capacity for the template protein $\mathrm{BHb}$. Recent progress has been made in using MMIPs for preparing and analyzing food samples. ${ }^{22}$ Moreover, molecularly imprinted core-shell magnetic nanoparticles were applied for selective enrichment of proteins in MALDI-TOF MS analysis. $^{23}$

In this study, magnetic nanoparticles, which were functionalized by silane and acrylic groups, were coated by the synthesized bovine hemoglobin (BHb) imprinted polymer. A transmission electron microscope (TEM) was used to observe the morphologies and structures of MMIPs. The chemical functionalities on the surface of the modified MMIPs were determined by Fourier transform infrared spectroscopy (FT-IR). The components and magnetic content of the MMIPs were investigated by thermo-gravimetric (TG) analysis. ${ }^{24}$ The dynamic adsorption, isothermal adsorption, reusability and the effect of different $\mathrm{pH}$ towards adsorption were investigated. In addition, the specific adsorption of MMIP towards BHb was determined by SDS-PAGE electrophoresis.

\section{Materials and methods}

\subsection{Materials}

The chemicals $25 \%$ ammonia solution $\left(\mathrm{NH}_{3} \cdot \mathrm{H}_{2} \mathrm{O}\right)$, iron(II) sulfate heptahydrate $\left(\mathrm{FeSO}_{4} \cdot 7 \mathrm{H}_{2} \mathrm{O}\right)$, iron(III) chloride hexahydrate $\left(\mathrm{FeCl}_{3} \cdot 6 \mathrm{H}_{2} \mathrm{O}\right)$, ethanol $\left(\mathrm{C}_{2} \mathrm{H}_{5} \mathrm{OH}\right)$, tetraethyl orthosilicate (TEOS), acrylic acid (AA), methacrylic acid (MAA), and itaconic acid (IA) were all of analytical reagent grade and used without further purification. Ovalbumin (OVA), bovine serum albumin (BSA) and bovine hemoglobin (BHb) were purchased from Sinopharm Chemical Reagent Co. Ltd (Shanghai, China). Highly pure water with an electrical resistivity of $18.2 \mathrm{M} \Omega \mathrm{cm}^{-1}$ was used throughout all the experiments.

\subsection{Synthesis of $\mathrm{Fe}_{3} \mathrm{O}_{4} @ \mathrm{SiO}_{2}-\mathrm{AA}$ nanoparticles}

According to the method of chemical precipitation of the $\mathrm{Fe}_{3} \mathrm{O}_{4}$ reported by Liu et al. ${ }^{25}$ and the decoration of the groups of $\mathrm{O}-\mathrm{Si}-$ $\mathrm{O}$ and $-\mathrm{COOH}$ reported by Guo et al., ${ }^{26}$ the $\mathrm{Fe}_{3} \mathrm{O}_{4} @ \mathrm{SiO}_{2}-\mathrm{AA}$ nanoparticles were prepared as follows. $\mathrm{Fe}_{3} \mathrm{O}_{4} \cdot 7 \mathrm{H}_{2} \mathrm{O}(0.80 \mathrm{~g})$ and $\mathrm{FeCl}_{3} \cdot 6 \mathrm{H}_{2} \mathrm{O}(1.17 \mathrm{~g})$ were dissolved in deionized water $(200 \mathrm{~mL})$ and absolute ethanol $(40 \mathrm{~mL})$ in a four-neck flask with mechanical agitation of $900 \mathrm{rpm}$ protected by nitrogen $\left(\mathrm{N}_{2}\right)$ flow. Under stirring for $0.5 \mathrm{~h}$ at $60{ }^{\circ} \mathrm{C}$, a $25 \% \mathrm{NH}_{3} \cdot \mathrm{H}_{2} \mathrm{O}$ aqueous solution $(5 \mathrm{~mL})$ was added to the mixture, changing the $\mathrm{pH}$ of the solution to 10-11, and transforming the solution color from orange to black. ${ }^{25}$ After $10 \mathrm{~min}$, the reaction mixture of $\mathrm{Fe}_{3} \mathrm{O}_{4}$ was cooled to $30{ }^{\circ} \mathrm{C}$, and a mixture of TEOS $(1 \mathrm{~mL})$ and ethanol $(20 \mathrm{~mL})$ was added dropwise to the solution. After reacting for $2 \mathrm{~h}$ with stirring at $900 \mathrm{rpm}$, the product $\mathrm{Fe}_{3} \mathrm{O}_{4} @ \mathrm{SiO}_{2}$ was placed in an external magnetic field. The supernatant was removed when the magnetic nanoparticles were gathered. After washing several times with deionized water, the magnetic nanoparticles were dispersed in a mixture of AA $(5 \mathrm{~mL})$ and ethanol $(160 \mathrm{~mL})$, followed by reaction at $30{ }^{\circ} \mathrm{C}$ for $2 \mathrm{~h}$. The functionalized superparamagnetic nanoparticles were then separated by a permanent magnet and washed several times with super pure water and ethanol, in sequence. Finally, the product $\mathrm{Fe}_{3} \mathrm{O}_{4} @ \mathrm{SiO}_{2}$-AA was dried in vacuum.

\subsection{Preparation of magnetic molecular imprinted nanoparticles (MMIPs) and non-molecular imprinted nanoparticles (NMIPs)}

With reference to the research reported by Guo et al., ${ }^{26}$ the MMIPs and NMIPs were prepared in a convenient and rapid way as described below. Initially, $60 \mathrm{mg} \mathrm{Fe}_{3} \mathrm{O}_{4} @ \mathrm{SiO}_{2}$-AA particles were mixed with methacrylic acid (MAA, $70 \mu \mathrm{L}$ ) and itaconic acid (IA, $25 \mathrm{mg}$ ) as functional monomers and $N^{\prime}, N$-methylenebisacrylamide $\left(N^{\prime}, N\right.$-MBA, $\left.16 \mathrm{mg}\right)$ as a crosslinking agent, dispersed in $20 \mathrm{~mL}$ PBS aqueous solution (0.02 M, pH 7). After ultrasonic vibration for $20 \mathrm{~min}$, the template protein $\mathrm{BHb}$ $(10 \mathrm{mg}$ ) was added into the mixture to prepare the MMIPs. The mixed solution was stirred at $25{ }^{\circ} \mathrm{C}$ at a shaking bath speed of $150 \mathrm{rpm}$ for $1 \mathrm{~h}$ to pre-assemble the mixtures, followed by purging with a nitrogen steam for $10 \mathrm{~min}$. Then, $70 \mu \mathrm{L}$ APS (20\%) and $14 \mu \mathrm{L}$ TEMED were added into the above suspension to initiate the reaction. After shaking at $25{ }^{\circ} \mathrm{C}$ at a speed of $150 \mathrm{rpm}$ for $12 \mathrm{~h}$, the precipitate was collected by a permanent magnet and cleaned by deionized water to remove the extra $\mathrm{BHb}$ and the unreacted monomers. The template proteins proceeded to be removed from the MMIPs using SDS-HAc aqueous (2\%, $2 \%$ ) as the eluent until the supernatant displayed no absorption at the detection wavelength of $406 \mathrm{~nm}$. Then, the MMIPs were washed with deionized water to eliminate the residue eluent and then dried in vacuum. The NMIPs were prepared using the same procedures as described above except for the addition of the template protein $\mathrm{BHb}^{26}$

\subsection{Adsorption experiments of protein}

The protein solution using phosphate buffer solution (PBS) as solvent was freshly prepared to determine the adsorption. The isothermal adsorption experiments were conducted by mixing $5 \mathrm{mg}$ MMIPs and $2 \mathrm{~mL} \mathrm{BHb}-\mathrm{PBS}(0.02 \mathrm{M}, \mathrm{pH} 7)$ with different initial concentrations $\left(0.2 \mathrm{mg} \mathrm{mL}^{-1}, 0.4 \mathrm{mg} \mathrm{mL}^{-1}, 0.6 \mathrm{mg} \mathrm{mL}^{-1}\right.$, $0.8 \mathrm{mg} \mathrm{mL}{ }^{-1}, 1.0 \mathrm{mg} \mathrm{mL}{ }^{-1}, 1.2 \mathrm{mg} \mathrm{mL}^{-1}, 1.4 \mathrm{mg} \mathrm{mL}^{-1}$, $1.6 \mathrm{mg} \mathrm{mL}{ }^{-1}$, and $1.8 \mathrm{mg} \mathrm{mL}^{-1}$ ), stirred at $25{ }^{\circ} \mathrm{C}$ in a shaking bath at a speed of $150 \mathrm{rpm}$ for $12 \mathrm{~h}$. The supernatants before and after absorption were detected by a UV-vis spectrophotometer (UV-5300, Hitachi, Tokyo, Japan) at $406 \mathrm{~nm}$ for the concentration of $\mathrm{BHb}$. The adsorption capacity $(Q)$ of the protein to the MMIPs was calculated using the following formula:

$$
Q=\frac{\left(C_{\mathrm{i}}-C_{\mathrm{f}}\right)}{m} V
$$

where $C_{\mathrm{i}}$ and $C_{\mathrm{f}}\left(\mathrm{mg} \mathrm{mL}^{-1}\right)$ refer to the initial and final concentrations of the absorbed protein solution, $V(\mathrm{~mL})$ is the volume of protein solution, and $m(\mathrm{mg})$ is the mass of the MMIPs.

For the kinetics, $5 \mathrm{mg}$ MMIPs and $2 \mathrm{~mL} \mathrm{BHb}-\mathrm{PBS}(0.02 \mathrm{M}$, $\mathrm{pH} 7$ ) with an initial concentration of $1.0 \mathrm{mg} \mathrm{mL}^{-1}$ was mixed and stirred at $25^{\circ} \mathrm{C}$ in a shaking bath at a speed of $150 \mathrm{rpm}$ for 
different times $(0.5 \mathrm{~h}, 1.0 \mathrm{~h}, 1.5 \mathrm{~h}, 2.0 \mathrm{~h}, 2.5 \mathrm{~h}, 3.0 \mathrm{~h}, 3.5 \mathrm{~h}, 4.0 \mathrm{~h}$, 5.0 h, 6.0 h, 7.0 h, 8.0 h, 9.0 h, 10.0 h, 11.0 h, and 12.0 h).

To investigate the influence of $\mathrm{pH}$ on the adsorption capability, $5 \mathrm{mg}$ MMIPs and $2 \mathrm{~mL}$ BHb $\left(1 \mathrm{mg} \mathrm{mL}^{-1}\right)$-PBS (0.02 M) with different $\mathrm{pH}(5.4,5.8,6.2,6.6,7.0,7.4,7.8$, and 8.2) was mixed and stirred at $25{ }^{\circ} \mathrm{C}$ in a shaking bath at a speed of $150 \mathrm{rpm}$ for $12 \mathrm{~h}$.

For the specific adsorption of MMIPs, $5 \mathrm{mg}$ of both MMIPs and NMIPs were added into a $2 \mathrm{~mL}$ protein mixture of ovalbumin, bovine hemoglobin and bovine serum (concentration of $\left.0.5 \mathrm{mg} \mathrm{mL}^{-1}\right)$ for an oscillating adsorption experiment $(12 \mathrm{~h}$, PBS $0.02 \mathrm{M}$ buffer solution). After $12 \mathrm{~h}$, the supernatant was removed and used for SDS-PAGE electrophoresis experiments. After adsorption, both the MMIPs and NMIPs were eluted with $5 \mathrm{~mL}$ eluent ( $2 \% \mathrm{SDS}$ ) for $12 \mathrm{~h}$ and finally, the eluent was also used for SDS-PAGE electrophoresis experiments.

\subsection{Characterization}

The morphologies and structures of $\mathrm{Fe}_{3} \mathrm{O}_{4}$, MMIPs, and NMIPs were examined by TEM (JEM-1200EX, JEOL, Tokyo, Japan) operating at $120 \mathrm{kV}$. The chemical functionalities on the surface of the modified nanoparticles were determined with FT-IR (Nicolet iS10, Thermo Scientific Corporation Wisconsin, USA) over a range of $0-4000 \mathrm{~cm}^{-1}$. The components of the functional nanoparticles were investigated by TG analysis (Q50, TA Instruments, USA) with a heating rate of $20^{\circ} \mathrm{C} \mathrm{min}^{-1}$ from $30{ }^{\circ} \mathrm{C}$ to $800{ }^{\circ} \mathrm{C}$. The PI of the nanoparticles was evaluated by a Zetasizer nano series (Nano-ZS, Malvern Instruments Ltd., UK) after the adjustment of $\mathrm{pH}$ with $\mathrm{HCl}(0.05 \mathrm{M})$ and $\mathrm{NaOH}$ $(0.05 \mathrm{M})$.

\section{Results and discussion}

\subsection{Preparation of MMIPs}

The synthesis route of MMIPs is illustrated in Scheme 1. Synthesized by chemical precipitation under high stir speed, the $\mathrm{Fe}_{3} \mathrm{O}_{4}$ particles are smaller with more special surface areas and magnetism. Accordingly, the naked $\mathrm{Fe}_{3} \mathrm{O}_{4}$ particles are easier to gather together by magnetic attraction. With the addition of TEOS, the $\mathrm{O}-\mathrm{Si}-\mathrm{O}$ groups were drawn onto the surface of the $\mathrm{Fe}_{3} \mathrm{O}_{4}$ particles and formed a silica shell to protect $\mathrm{Fe}_{3} \mathrm{O}_{4}$ from magnetic attraction and oxidation. The adoption of acrylic acid provides the vinyl groups and the carboxyl groups, which increase the amount of active groups on the surface of the particles and provide binding sites for the subsequent reaction. ${ }^{27}$ At the stage of $\mathrm{BHb}$ pre-assembly, the active groups of $\mathrm{BHb}$ such as $-\mathrm{OH},-\mathrm{COOH}$ and $-\mathrm{NH}_{2}$ combined with those of $\mathrm{Fe}_{3} \mathrm{O}_{4} @ \mathrm{SiO}_{2}$-AA particles through hydrogen bonding, resulting in temporarily immobilization on the surface of $\mathrm{Fe}_{3} \mathrm{O}_{4} @ \mathrm{SiO}_{2}$-AA. Using MAA and IA as functional monomers and $N^{\prime}, N$-MBA as a crosslinker, the copolymerization occurred, forming the molecular imprinted polymers covering the surface of $\mathrm{Fe}_{3} \mathrm{O}_{4} @ \mathrm{SiO}_{2}$-AA particles. After removing the template $\mathrm{BHb}$ in the polymers with eluent, the cavities were obtained in the polymers, which are complementary to the target proteins in morphological structure, size and functional group orientation.

\subsection{Characterization}

3.2.1. FT-IR characterization. FT-IR is usually used to characterize chemical bonds and functional groups. As shown in Fig. 1, the strong absorption peaks at $590 \mathrm{~cm}^{-1}$, corresponding to the stretching vibration of the $\mathrm{Fe}-\mathrm{O}$ bond, were characteristic of all the magnetic particles. A sharp peak at $1090 \mathrm{~cm}^{-1}$, referring to the $\mathrm{Si}-\mathrm{O}-\mathrm{Si}$ asymmetric stretching vibration, suggested the formation of silicone hydride in both $\mathrm{Fe}_{3} \mathrm{O}_{4} @ \mathrm{SiO}_{2}$-AA and MMIPs as compared to naked $\mathrm{Fe}_{3} \mathrm{O}_{4} \cdot{ }^{25}$ The characteristic peak at both $1630 \mathrm{~cm}^{-1}$ and $3400 \mathrm{~cm}^{-1}$ of $-\mathrm{OH}$ indicated that there were abundant hydroxyl groups on $\mathrm{Fe}_{3} \mathrm{O}_{4}$ and $\mathrm{Fe}_{3} \mathrm{O}_{4} @ \mathrm{SiO}_{2}$-AA. The same characteristic $-\mathrm{OH}$ peak on the curve of MMIPs shifted to the higher wavenumber of $1650 \mathrm{~cm}^{-1}$ and became stronger by the influence of $-\mathrm{C}=\mathrm{O}$, suggesting that $-\mathrm{C}=\mathrm{O}$ and $-\mathrm{OH}$ both existed on the MMIPs. The peak at $1540 \mathrm{~cm}^{-1}$ assigned to $-\mathrm{NH}_{2}$ and the peak at $2923 \mathrm{~cm}^{-1}$ attributed to $\mathrm{C}-\mathrm{H}$ demonstrated the successful introduction and polymerization of the functional monomers and crosslinker.
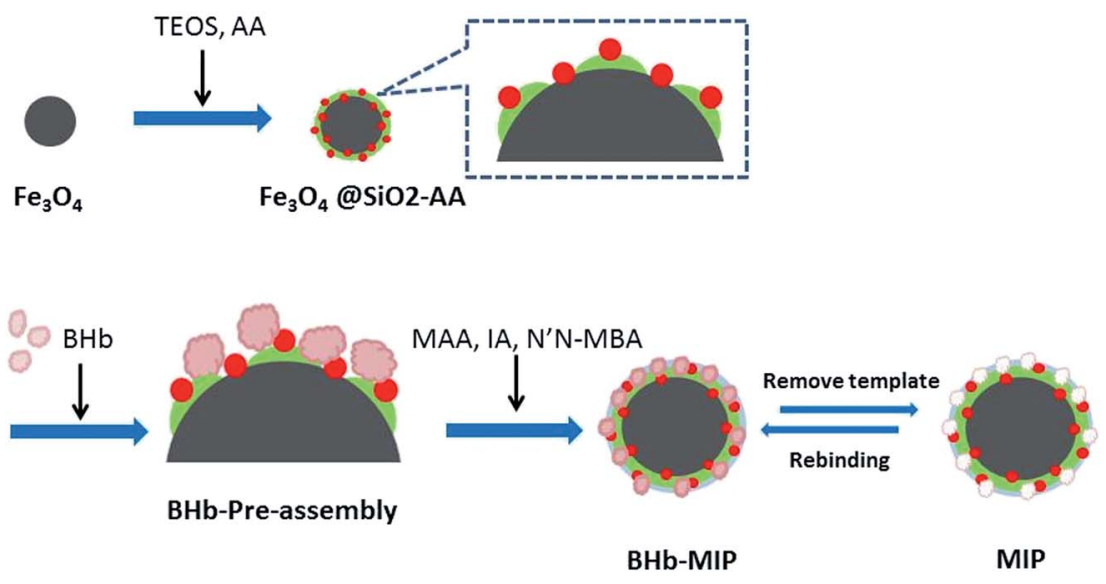

Scheme 1 Synthesis route for MMIPs. 


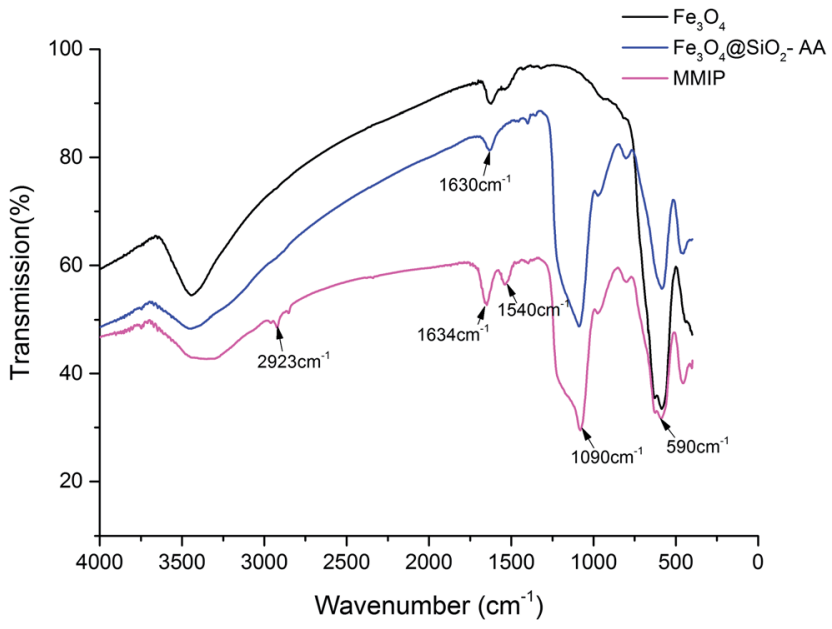

Fig. 1 FTIR spectrum of $\mathrm{Fe}_{3} \mathrm{O}_{4}, \mathrm{Fe}_{3} \mathrm{O}_{4} \mathrm{CSiO}_{2}-\mathrm{AA}$ and MMIPs.

\subsubsection{TEM characterization}

The size and morphological structure of naked $\mathrm{Fe}_{3} \mathrm{O}_{4}, \mathrm{Fe}_{3}$ $\mathrm{O}_{4} @ \mathrm{SiO}_{2}-\mathrm{AA}$ and MMIPs are illustrated in Fig. 2. The diameter of the $\mathrm{Fe}_{3} \mathrm{O}_{4}$ particles (Fig. 2A) was about $20 \mathrm{~nm}$; the space between $\mathrm{Fe}_{3} \mathrm{O}_{4}$ particles was narrow. As shown in Fig. 2B, the diameter of MMIPs was supposed to be around $25 \mathrm{~nm}$, which indicated that the molecular imprinted polymer coated on the MMIPs was sufficiently thin and suitable for the capture of $\mathrm{BHb}$. As shown in Fig. 2, the MMIP (Fig. 2B) and NMIP (Fig. 2C) particles were more dispersive as compared to the $\mathrm{Fe}_{3} \mathrm{O}_{4}$ particles (Fig. 2A); thus, it can be concluded that the polymeric coating had appropriately shielded the magnetite and significantly reduced the aggregation of the particles. ${ }^{28}$

\subsubsection{TGA analysis}

To analyze the components and the concentration of iron oxide in the functional nanoparticles, TGA analysis was performed; the resultant curves are illustrated in Fig. 3. When the temperature increased gradually from 30 to $250{ }^{\circ} \mathrm{C}$, all of the $\mathrm{Fe}_{3} \mathrm{O}_{4}, \mathrm{Fe}_{3} \mathrm{O}_{4} @ \mathrm{SiO}_{2}$-AA and MMIPs lost about 5.5\% mass, which was caused by evaporation of water on the surface and the decomposition of some trace impurities. At the temperature range of $250-500{ }^{\circ} \mathrm{C}$, the total weight loss increased to $12.3 \%$ of $\mathrm{Fe}_{3} \mathrm{O}_{4} @ \mathrm{SiO}_{2}$-AA and MMIP, which indicated the loss of the silicone hydride group and acrylic acid group. In the temperature range of $500-800{ }^{\circ} \mathrm{C}$, the curve of $\mathrm{Fe}_{3} \mathrm{O}_{4} @ \mathrm{SiO}_{2}$-AA particles

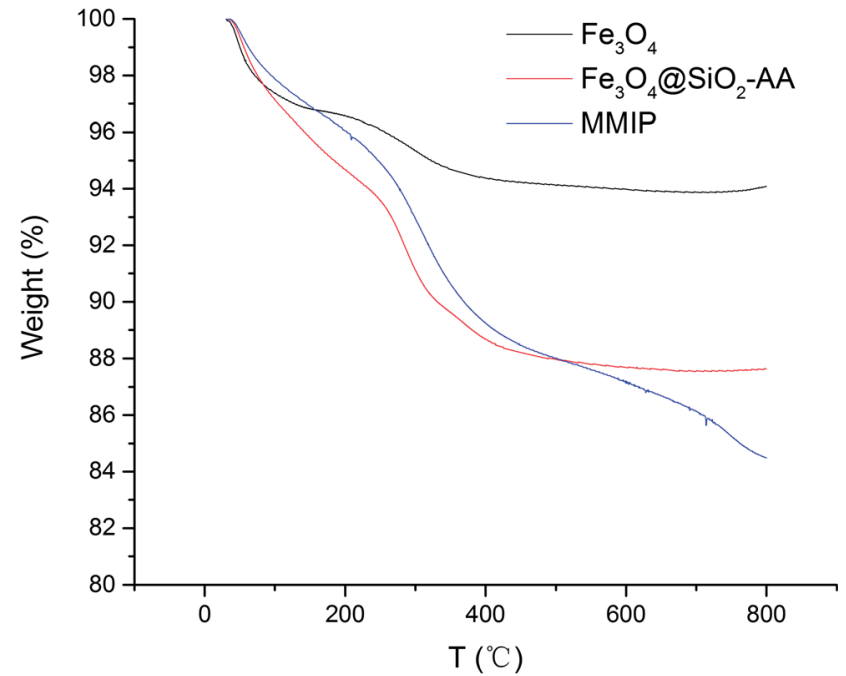

Fig. 3 TGA curves of $\mathrm{Fe}_{3} \mathrm{O}_{4}, \mathrm{Fe}_{3} \mathrm{O}_{4} \mathrm{CSiO}_{2}-\mathrm{AA}$ and MMIPs.

became stable, while the weight loss in this stage of MMIPs increased by $3.6 \%$, suggesting the degradation of the molecular imprinted polymer on the MMIPs. As shown in Fig. 3, the magnetic content of MMIPs was about $84 \%$, which was less than that of naked $\mathrm{Fe}_{3} \mathrm{O}_{4}$, but suitable for magnetic targeting and separation. ${ }^{25}$

\subsubsection{Investigation on the PI of functional magnetic nanoparticles}

The changes in zeta potential of the different magnetic particles with the solution $\mathrm{pH}$ are shown in Fig. 4. When the zeta potential reached zero, the electrostatic charge of the magnetic particle surface was zero. At this point, the $\mathrm{pH}$ of the solution was the isoelectric point (PI) of the magnetic particle. As shown in Fig. 4, the PI of $\mathrm{Fe}_{3} \mathrm{O}_{4}$ was about 3.50. The PI of $\mathrm{Fe}_{3} \mathrm{O}_{4} @ \mathrm{SiO}_{2}$ was about 2.50, while the PI of $\mathrm{Fe}_{3} \mathrm{O}_{4} @ \mathrm{SiO}_{2}$-AA was about 2.75. This was because the silane modified on the surface of magnetic particles brought a large number of active $-\mathrm{OH}$ groups, while $\mathrm{Fe}_{3} \mathrm{O}_{4} @ \mathrm{SiO}_{2}$-AA modified with acrylic acid introduced a certain amount of $-\mathrm{COOH}$ groups. The MMIPs formed by molecular imprinting had a PI of about 4.5, possibly because of the $-\mathrm{NH}_{2}$ provided by the crosslinker and partially due to the functional monomers. This also indirectly proved that the magnetic particles were successfully modified with functional groups and molecularly imprinted layers.
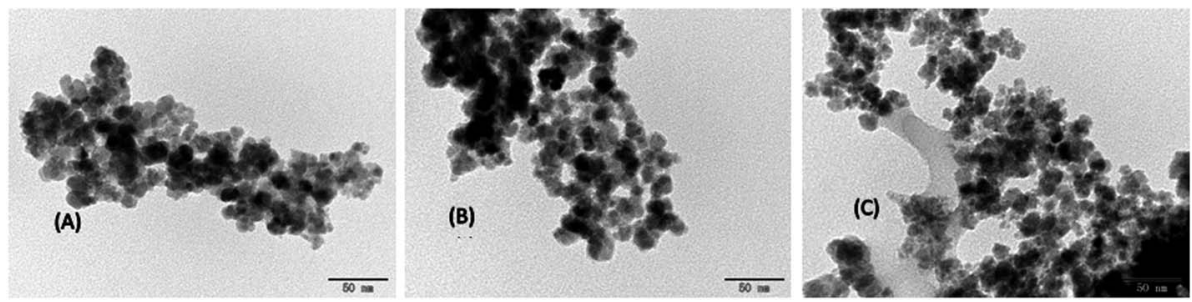

Fig. 2 Size characterizations of naked $\mathrm{Fe}_{3} \mathrm{O}_{4}$ (A), MMIPs (B) and NMIPs (C). 


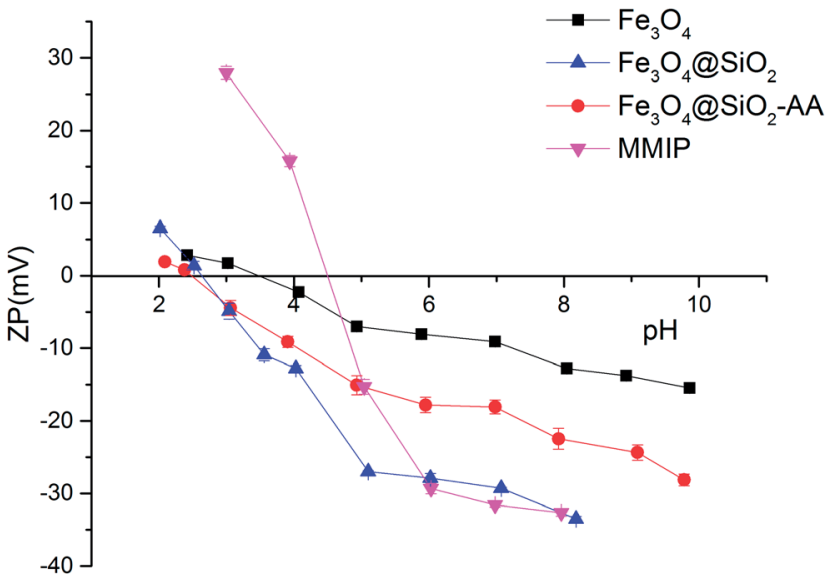

Fig. 4 Zeta potential of $\mathrm{Fe}_{3} \mathrm{O}_{4}, \mathrm{Fe}_{3} \mathrm{O}_{4} \mathrm{QSiO}_{2}, \mathrm{Fe}_{3} \mathrm{O}_{4}\left(\mathrm{aSiO}_{2}-\mathrm{AA}\right.$ and MMIPs.

\subsection{Adsorption performance}

3.3.1. Dynamic adsorption. To investigate the dynamic adsorption of $\mathrm{BHb}$ onto MMIPs, the changes in adsorption capability versus time are illustrated in Fig. 5 . It can be easily concluded that the adsorption capability of MMIPs increased rapidly within $1 \mathrm{~h}$, and then significantly slowed down. The rebinding capability sluggishly increased after $1 \mathrm{~h}$ because the patterns of the cavities for the template on the surface of MMIPs varied widely and the mass-transfer resistance became higher after most BHb was bound to the MMIPs. Nevertheless, the maximum adsorption capability of MMIPs can reach to $116.69 \mathrm{mg} \mathrm{mL}^{-1}$, which is much higher than that reported by $\mathrm{Fu}$ et $a .^{29}$

Some models were fitted to the variation of adsorption capacity with time. It was found that the adsorption process of MMIPs to $\mathrm{BHb}$ was more in line with the pseudo second-order kinetic model. The pseudo second-order kinetic formula can be expressed as follows:

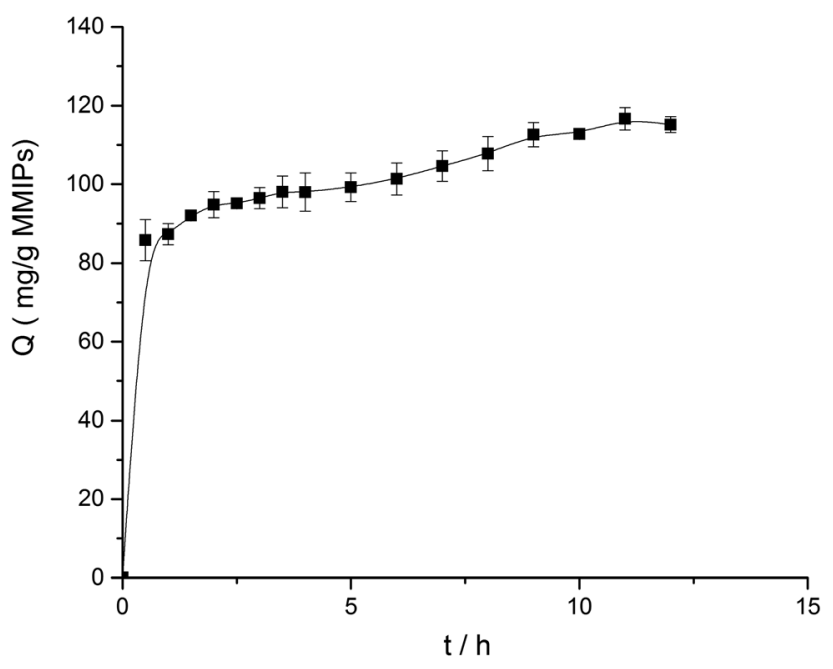

Fig. 5 Effect of the rebinding time on adsorption capability.

$$
\frac{t}{Q}=\frac{1}{K_{2} Q_{\mathrm{e}}^{2}}+\frac{1}{Q_{\mathrm{e}}} t
$$

where $Q$ and $Q_{\mathrm{e}}\left(\mathrm{mg} \mathrm{g}^{-1}\right)$ referred to the amounts of $\mathrm{BHb}$ absorbed by MMIPs with time and at equilibrium, respectively; $K_{2}\left(\min ^{-1}\right)$ and $t(\mathrm{~h})$ refer to the rate constant of second-order adsorption and the rebinding time, respectively.

According to formula (2), the curve of $t / Q$ versus time was obtained (Fig. 6). The fitting equation was $y=0.0084 x+0.0052$. The correlation coefficient $R^{2}$ was 0.9948 , greater than 0.99 , which indicated that the second-order kinetics is suitable for describing the adsorption process of MMIPs to BHb. From the fitted equation, the maximum adsorption capacity of MMIPs to BHb was $192.31 \mathrm{mg} \mathrm{mL}^{-1}$.

3.3.2. Isothermal adsorption. In this study, $5 \mathrm{mg}$ MMIPs were mixed with $2 \mathrm{~mL} \mathrm{BHb}$ with different concentrations for $12 \mathrm{~h}$ of dynamic rebinding. The maximum adsorption amount of $\mathrm{BHb}$ on MMIPs at different initial concentrations of $\mathrm{BHb}$ was studied. As shown in Fig. 7, with an increase in $\mathrm{BHb}$ initial concentration, the equilibrium adsorption capacity of MMIPs to $\mathrm{BHb}$ increased continuously. When the initial concentration of $\mathrm{BHb}$ increased to $1.0 \mathrm{mg} \mathrm{mL}^{-1}$, the adsorption capacity of MMIPs to $\mathrm{BHb}$ tended to be at equilibrium. This suggests that the cavities on MMIPs for combining with $\mathrm{BHb}$ approached saturation at the initial $\mathrm{BHb}$ concentration of $1.0 \mathrm{mg} \mathrm{mL}^{-1}$. The $\mathrm{BHb}$ adsorption process of MMIPs at different initial concentrations was fitted to the Langmuir isotherm model. The Langmuir isothermal adsorption formula is as follows:

$$
\frac{C_{\mathrm{e}}}{Q}=\frac{C_{\mathrm{e}}}{Q_{\mathrm{m}}}+\frac{1}{Q_{\mathrm{m}} k}
$$

where $Q$ and $Q_{\mathrm{m}}\left(\mathrm{mg} \mathrm{g}^{-1}\right)$ refer to the amounts of BHb absorbed by MMIPs with time and at equilibrium, respectively; $C_{\mathrm{e}}$ represents the concentration of $\mathrm{BHb}$ at equilibrium $\left(\mathrm{mg} \mathrm{mL}^{-1}\right)$; $k$ is the adsorption equilibrium constant of the Langmuir model.

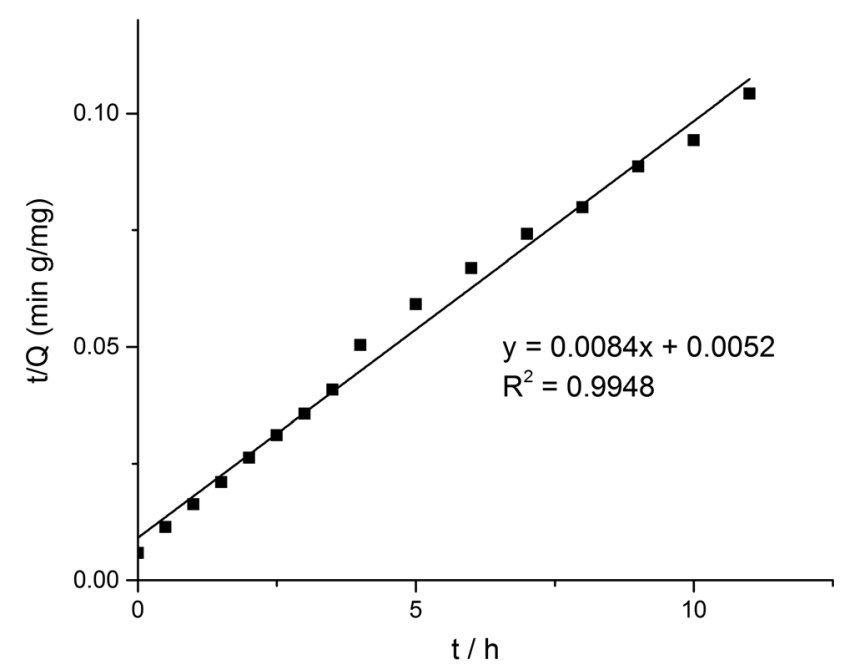

Fig. 6 Pseudo second-order kinetics of the adsorption of $\mathrm{BHb}$ by MMIPS. 


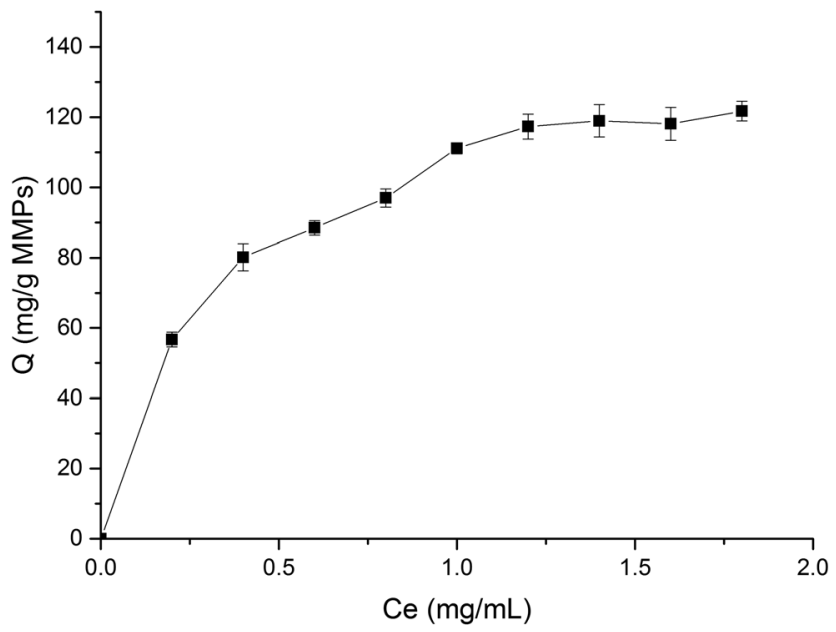

Fig. 7 Effect of the initial concentration of $\mathrm{BHb}$ towards the adsorption capability.

As shown in Fig. 8, the fitting equation for the adsorption capability of MMIPs on BHb using Langmuir was $y=0.0067 x+$ 0.0024; the maximum adsorption capacity of MMIPs on BHb was $149.25 \mathrm{mg} \mathrm{mL}^{-1}$ according to the equation, which was higher than that obtained by Gao et al. ${ }^{30}$ The correlation coefficient $R^{2}$ obtained by fitting was 0.9906 , which indicated that the adsorption process was well-described by the Langmuir adsorption model.

\subsection{Reusability of MMIPs}

To investigate the reusability of MMIPs, the BHb absorbed on the MMIPs was eluted by a $2 \%$ SDS-HAc solution and then, the MMIPs were used to rebind the BHb several times repeatedly. Fig. 9 shows the high and stable adsorption of the MMIPs after five times of reuse, which reflected the favourable reusability of MMIPs.

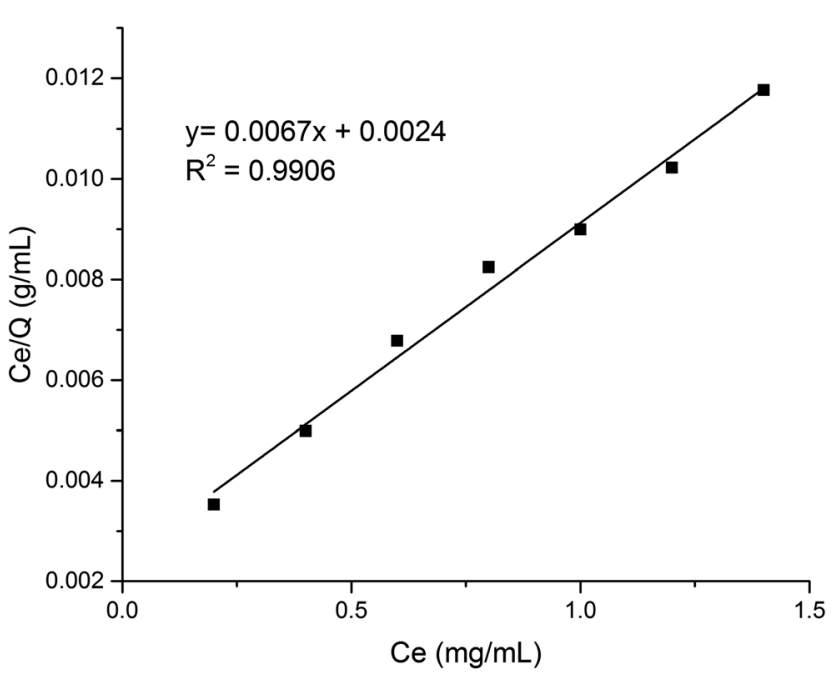

Fig. 8 Langmuir plot of the adsorption of $\mathrm{BHb}$ by MMIPs.

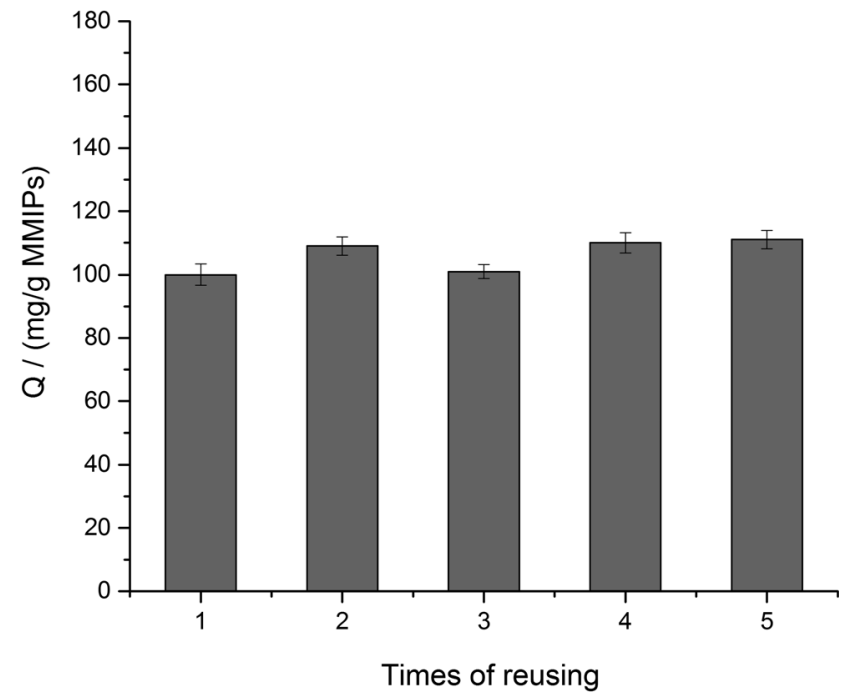

Fig. 9 Adsorption of MMIPs by reusing several times.

\subsection{Effect of different $\mathrm{pH}$ on the adsorption of MMIPs}

In this study, the equilibrium adsorption capacity of MMIPs on $\mathrm{BHb}$ was investigated at different $\mathrm{pH}$ at $25{ }^{\circ} \mathrm{C}$ (PBS buffer, $0.02 \mathrm{M}$ ). As shown in Fig. 10, when the pH of the BHb solution increased from 5.4 to 6.2 , the adsorption capacity of MMIPs to $\mathrm{BHb}$ increased gradually. However, when the $\mathrm{pH}$ of the solution increased from 6.2 to 8.2, the adsorption of MMIPs to BHb decreased gradually. Therefore, the amount of BHb adsorbed by MMIPs reached a maximum of $169.29 \mathrm{mg} \mathrm{g}^{-1}$ at a solution $\mathrm{pH}$ of about 6.2. As previously concluded, the PI of MMIPs was about 4.5 , while the $\mathrm{PI}$ of $\mathrm{BHb}$ was about 6.8 . In the $\mathrm{pH}$ range of 4.5-6.8, increasing the $\mathrm{pH}$ gradually increases the negative charges on MMIPs, while the positive charges on BHb decreases gradually. Therefore, at a defined $\mathrm{pH}$ value the electrostatic adsorption between MMIPs and BHb reaches a maximum. This is why the MMIPs obtained a maximum adsorption capacity of

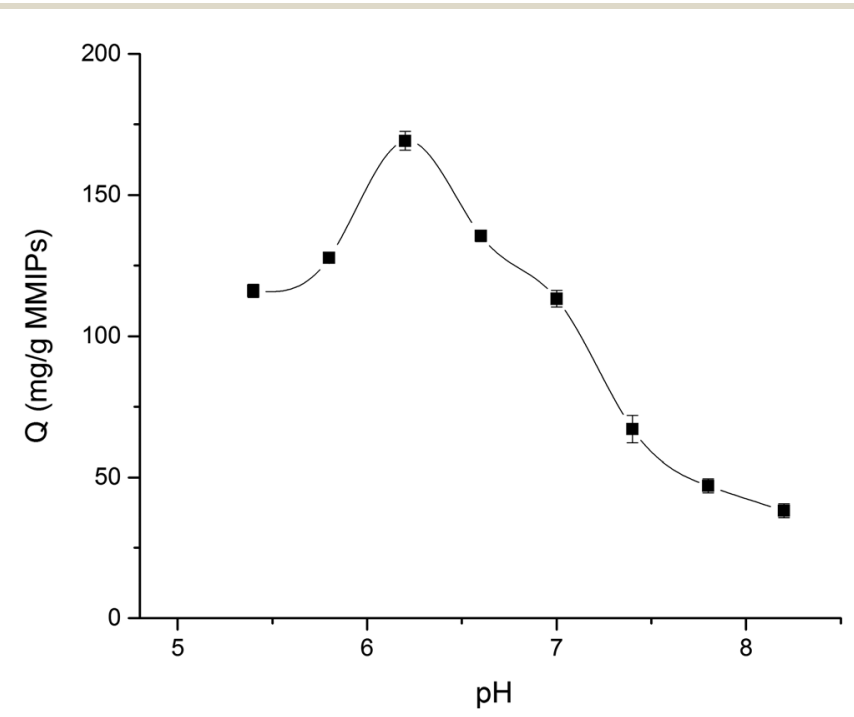

Fig. 10 Effect of different $\mathrm{pH}$ on adsorption capability. 

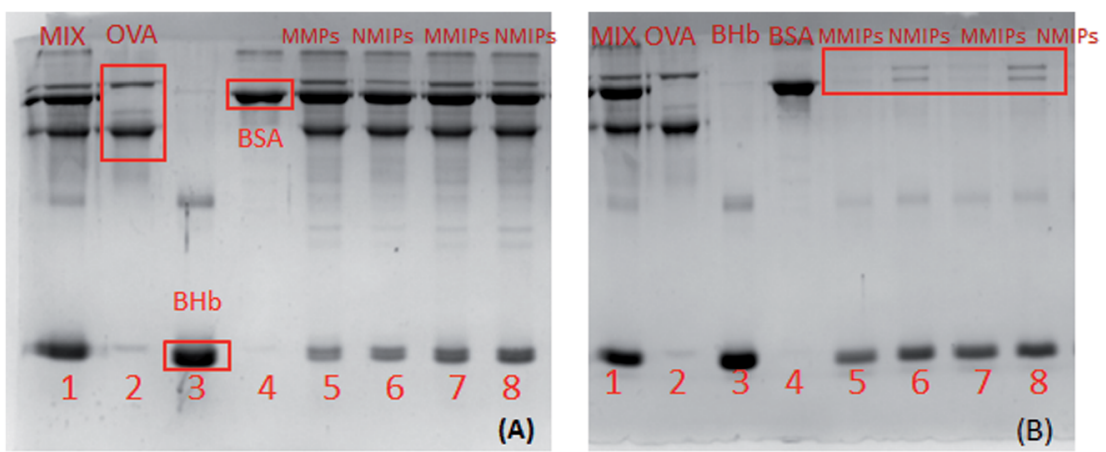

Fig. 11 SDS-PAGE of selective adsorptions of nanoparticles on $\mathrm{BHb}$ (supernatant of the mixture after adsorption by nanoparticles (A), eluent from nanoparticles after $12 \mathrm{~h}$-elution (B), mixture of three protein (A-1, B-1), solution of OVA (A-2, B-2), solution of BHb (A-3, B-3), solution of BSA (A-4, B-4), supernatant of the mixture after adsorption by MMIPs (A-5, A-7), supernatant of mixture after adsorption by NMIPs (A-6, A-8), eluent from MMIPs after $12 \mathrm{~h}$-elution (B-5, B-7), eluent from NMIPs after 12 h-elution (B-6, B-8)).

$\mathrm{BHb}$ at $\mathrm{pH}$ 6.2. This also indicates that at a suitable $\mathrm{pH}$ value, the electrostatic interaction between MMIPs and BHb can promote the adsorption ability.

\subsection{Selective adsorption}

As shown in Fig. 11(A), in the protein mixture adsorbed by MMIPs, the color of the $\mathrm{BHb}$ band turned shallow, while there were no visible changes in the other protein bands (Lane 5 and 7 in Fig. 11A). Comparatively, in the mixed solution after adsorption by NMIPs, not only the band of $\mathrm{BHb}$, but also the bands of OVA and BSA became shallow (Lane 6 and 8 in Fig. 11A). As shown in Fig. 11(B), in the solution of protein eluted from MMIPs, only the band of $\mathrm{BHb}$ can be observed (Lane 5 and 7 in Fig. 11B). For the eluent from NMIPs, all of the bands of BHb, OVA and BSA can be observed (Lane 6 and 8 in Fig. 11B). It can be adequately demonstrated that MMIPs can selectively adsorb the template protein. By comparison, the NMIPs, prepared by the same synthesis process as the MMIPs except for the imprinting of template protein, could not to achieve the specific adsorption of the template protein because of the lack of specific cavities that are complementary with the target protein.

\section{Conclusion}

In this study, molecularly imprinted magnetic nanoparticles were prepared by using $\mathrm{BHb}$ as the template protein on the basis of core-shell functionalized nanoparticles modified with silyl and acrylate groups. The magnetic particles with small volume, large specific surface area, good dispersibility, and abundant cavities, complementary with template proteins in morphology, structure, size and binding groups, can achieve ample protein adsorption in short time with high specificity. In addition, MMIPs with high magnetic content can be rapidly separated from the solution under an applied magnetic field. Therefore, molecularly imprinted magnetic nanoparticles have significant effects and broad prospects in the isolation and enrichment of specific proteins in the food, medicine and biological research fields.

\section{Conflicts of interest}

The authors declare that there are no conflicts of interest.

\section{Acknowledgements}

This work was supported by the National Natural Science Foundation of China (No. 31501428) and the Jiangsu province "Collaborative Innovation Center for Food Safety and Quality Control” industry development program.

\section{References}

1 T. Y. Li, L. S. Fan, Y. F. Wang, X. B. Huang, J. G. Xu, J. X. Lu, M. Zhang and W. Xu, Anal. Chem., 2017, 89, 1453-1458.

2 Z. Altintas, M. J. Abdin, A. M. Tothill, K. Karim and I. E. Tothill, Anal. Chim. Acta, 2016, 935, 239-248.

3 S. A. Zaidi, RSC Adv., 2016, 6, 88807-88819.

4 L. Mergola, S. Scorrano, R. Del Sole, M. R. Lazzoi and G. Vasapollo, Biosens. Bioelectron., 2013, 40, 336-341.

5 P. Lenain, J. D. Di Mavungu, P. Dubruel, J. Robbens and S. De Saeger, Anal. Chem., 2012, 84, 10411-10418.

6 R. J. Ansell and K. Mosbach, J. Chromatogr. A, 1997, 787, 5566.

7 C. J. Tan, M. G. Chua, K. H. Ker and Y. W. Tong, Anal. Chem., 2008, 80, 683-692.

8 N. Sankarakumar and Y. W. Tong, RSC Adv., 2013, 3, 15191527.

9 K. Hosoya, K. Yoshizako, N. Tanaka, K. Kimata, T. Araki and J. Haginaka, Chem. Lett., 1994, 1437-1438, DOI: 10.1246/ Cl.1994.1437.

10 N. Phutthawong and M. Pattarawarapan, J. Appl. Polym. Sci., 2013, 128, 3893-3899.

11 W. M. Li, M. M. Chen, H. Y. Xiong, W. Wen, H. P. He, X. H. Zhang and S. F. Wang, New J. Chem., 2016, 40, 564-570.

12 T. Zhu, D. Xu, Y. G. Wu, J. Li, M. M. Zhou, T. Tian, Y. Jiang, F. T. Li and G. T. Li, J. Mater. Chem. B, 2013, 1, 6449-6458.

13 M. Zhang, X. H. Zhang, X. W. He, L. X. Chen and Y. K. Zhang, Nanoscale, 2012, 4, 3141-3147. 
14 J. L. Cao, X. H. Zhang, X. W. He, L. X. Chen and Y. K. Zhang, Chem.-Asian J., 2014, 9, 526-533.

15 X. D. Mao, H. Y. Sun, X. W. He, L. X. Chen and Y. K. Zhang, Anal. Methods, 2015, 7, 4708-4716.

16 Y. R. Zhao, C. F. Bi, X. W. He, L. X. Chen and Y. K. Zhang, RSC Adv., 2015, 5, 70309-70318.

17 D. E. Hansen, Biomaterials, 2007, 28, 4178-4191.

18 A. Bossi, F. Bonini, A. P. F. Turner and S. A. Piletsky, Biosens. Bioelectron., 2007, 22, 1131-1137.

19 T. Jing, H. R. Du, Q. Dai, H. A. Xia, J. W. Niu, Q. L. Hao, S. R. Mei and Y. K. Zhou, Biosens. Bioelectron., 2010, 26, 301-306.

20 L. Li, X. W. He, L. X. Chen and Y. K. Zhang, Sci. China, Ser. B: Chem., 2009, 52, 1402-1411.

21 L. Li, X. W. He, L. X. Chen and Y. K. Zhang, Chem.-Asian J., 2009, 4, 286-293.

22 J. Ashley, M. A. Shahbazi, K. Kant, V. A. Chidambara, A. Wolff, D. D. Bang and Y. Sun, Biosens. Bioelectron., 2017, 91, 606-615.
23 Y. B. Liu, S. M. Fang, J. Q. Zhai and M. P. Zhao, Nanoscale, 2015, 7, 7162-7167.

24 Y. X. Li, Y. T. Chen, L. Huang, B. Y. Lou and G. N. Chen, Analyst, 2017, 142, 302-309.

25 F. Liu, F. G. Niu, N. Peng, Y. J. Su and Y. J. Yang, RSC $A d v$., 2015, 5, 18128-18136.

26 J. X. Guo, Y. Z. Wang, Y. J. Liu and Y. G. Zhou, Anal. Methods, 2015, 7, 10018-10025.

27 X. Kong, R. Gao, X. He, L. Chen and Y. Zhang, J. Chromatogr. A, 2012, 1245, 8-16.

28 Y. F. Wang, H. X. Jin, Y. G. Wang, L. Y. Yang, X. K. OuYang and W. J. Wu, Molecules, 2016, 21, 915.

29 G. Q. Fu, H. Y. He, Z. H. Chai, H. C. Chen, J. A. Kong, Y. Wang and Y. Z. Jiang, Anal. Chem., 2011, 83, 1431-1436.

30 R. X. Gao, L. L. Zhang, Y. Hao, X. H. Cui and Y. H. Tang, RSC Adv., 2014, 4, 64514-64524. 